\title{
Perkinsus beihaiensis (Perkinsozoa) in oysters of Bahia State, Brazil
}

\author{
M. S. A. Luz ${ }^{a}$, F. S. Carvalho ${ }^{a}$, H. C. Oliveira ${ }^{a}$ and G. Boehs ${ }^{a *}$ \\ aPostgraduate Animal Science Program, Universidade Estadual de Santa Cruz - UESC, Rod. Ilhéus-Itabuna, \\ Km 16, CEP 45652-900, Ilhéus, BA, Brazil \\ *e-mail: gboehs@uesc.br
}

Received: May 11, 2016 - Accepted: September 30, 2016 - Distributed: May 31, 2018

(With 3 figures)

\begin{abstract}
This study reports the pathogen Perkinsus beihaiensis in oysters of the genus Crassostrea on the coast of the State of Bahia (Brazil), its prevalence, infection intensity and correlation with salinity. Oysters $(\mathrm{n}=240)$ were collected between October and December 2014 at eight sampling stations between latitudes $13^{\circ} 55^{\prime} \mathrm{S}$ and $15^{\circ} 42^{\prime} \mathrm{S}$. The laboratory procedures included macroscopic analysis, histology, culture in Ray's fluid thioglycollate medium (RFTM), Polymerase Chain Reaction (PCR) and DNA sequencing. PCR and sequencing have been used for the genetic identification of oysters as well. Two species of oysters have been identified: Crassostrea rhizophorae and C. brasiliana. In both oyster species $P$. beihaiensis was the only Perkinsus species detected. In C. rhizophorae, the average prevalence was $82.8 \%$ by histology and $65.2 \%$ by RFTM. In C. brasiliana, the prevalences were $70.5 \%$ and $35.7 \%$, respectively. The higher prevalence of $P$. beihaiensis in $C$. rhizophorae was probably influenced by salinity, with which was positively correlated ( $r>0.8)$. In both oysters, P. beihaiensis was located mainly in the gastric epithelium. The infection was generally mild or moderate, without apparent harm to the hosts, but in cases of severe infection, there was hemocytical reaction and tissue disorganization. The generally high prevalence in the region suggests that oysters should be monitored with respect to this pathogen, especially in growing areas.
\end{abstract}

Keywords: bivalves, diseases, pathology, salinity.

\section{Perkinsus beihaiensis (Perkinsozoa) em ostras do Estado da Bahia}

\section{Resumo}

Este estudo relata o patógeno Perkinsus beihaiensis em ostras do gênero Crassostrea no litoral do Estado da Bahia (Brasil), sua prevalência, intensidade de infecção e correlação com a salinidade. As ostras $(\mathrm{n}=240)$ foram coletadas entre outubro e dezembro de 2014 em oito estações amostrais entre as latitudes $13^{\circ} 55^{\prime} \mathrm{S}$ e $15^{\circ} 42^{\prime} \mathrm{S}$. Os procedimentos laboratoriais incluíram análise macroscópica, histologia, cultivo em meio de tioglicolato de Ray (RFTM), reação em cadeia da polimerase (PCR) e sequenciamento de DNA. PCR e sequenciamento foram também utilizados para a identificação genética das ostras. Foram identificadas duas espécies de ostras: Crassostrea rhizophorae e C. brasiliana. Em ambas as espécies, $P$. beihaiensis foi a única espécie de Perkinsus detectada. Em C. rhizophorae, a prevalência média foi de $82,8 \%$ por histologia e de $65,2 \%$ por RFTM. Em C. brasiliana, as prevalências foram de $70,5 \%$ e $35,7 \%$, respectivamente. A maior prevalência de $P$. beihaiensis em $C$. rhizophorae foi provavelmente influenciada pela salinidade, com a qual este apresentou correlação positiva $(\mathrm{r}>0,8)$. Em ambas as espécies, $P$. beihaiensis esteve localizada principalmente no epitélio gástrico. A infecção foi geralmente leve ou moderada, sem danos aparentes aos hospedeiros, mas em casos de infecção severa, houve reação hemocitária e desorganização de tecidos. As prevalências geralmente altas na região sugerem que as ostras devam ser monitoradas com relação a este patógeno, principalmente em áreas de cultivo.

Palavras-chave: bivalves, doenças, patologia, salinidade.

\section{Introduction}

It is known that for the success of mollusks farming, management and monitoring of diseases are essential. According to review by Boehs et al. (2012), in the last decade have been recorded various pathogens in bivalve mollusks from the Brazilian coast, including representatives of bacteria, protozoa, fungi and metazoans. Nevertheless,

in general there is still few information on diseases in bivalves of economic interest, both in Brazil and throughout South America, particularly with regard to the life cycle of pathogens and the interaction of these with their hosts.

Among the pathogens already reported at Brazilian coast, is the genus Perkinsus Levine, 1978 (Perkinsozoa), 
which affects mollusks in various parts of the world, including some bivalves of great economic interest, such as oysters. Seven species are described worldwide, two of which (P. marinus and P. olseni) are notifiable to the World Organization for Animal Health (OIE, 2012). In Brazil, four species were recorded in the past five years, all in the Northeast: P. beihaiensis, P. marinus, P. olseni and P. chesapeaki (Dantas-Neto, 2015).

Perkinsus beihaiensis Moss, Xiao, Dungan and Reece, 2008 was first described in southern China (Moss et al., 2008) in Crassostrea ariakensis (Fujita, 1913) and in C. hongkongensis Lam and Morton, 2003. Sanil et al. (2012) reported this species in C. madrasensis (Preston, 1916) in India. In Brazil, P. beihaiensis was recorded in species of Crassostrea in northeastern Brazil, in the states of Ceará (Sabry et al., 2009, 2013), Paraíba (Queiroga et al., 2015) and Bahia (Luz and Boehs, 2016), as well as in Anomalocardia brasiliana (Gmelin, 1791) (Veneridae) (Ferreira et al., 2015) from Ceará. Overall, there is still few information on this species in terms of their ecology, potential hosts, and risks for the production of mollusks.

The oysters Crassostrea rhizophorae (Guilding, 1828) and C. brasiliana (Lamarck, 1819) are important resources for consumption and sale of extractive communities on the Brazilian coast. The cultivation of these mollusks is already practiced in several locations. This study reports the presence of $P$. beihaiensis in these species at Bahia State, with information about pathology, infection intensity, prevalence, and correlation with salinity.

\section{Material and Methods}

\subsection{Collections}

Sampling was done at eight sampling stations (St1-St8) located between latitudes $13^{\circ} 55^{\prime} \mathrm{S}$ and $15^{\circ} 42^{\prime} \mathrm{S}$, in a stretch of about $200 \mathrm{~km}$. Stations St1-St4 were located in the municipality of Camamu, St5 and St6 in Ilhéus and St7 and St8 in Canavieiras (Figure 1, Table 1). Samples were collected between October and December 2014, under authorization number 20912-3, granted by the Chico Mendes Institute for Biodiversity Conservation - ICMBio, Brazil.

The specimens were removed with the help of a knife, from the trunks or roots of red mangrove Rhizophorae mangle L. (St1-St5 and St8) or from rocks and concrete structures (St6 and St7), always during low tide periods. At each sampling station were collected 30 oysters. These were brought in buckets containing a small portion of sea water and processed in a period of 6 hours after their collection. Water temperature and salinity were recorded in each day of sampling using respectively a standard mercury thermometer and an optical refractometer Atago S/Mill.

\subsection{Laboratory procedures}

The oysters were measured for their long axis (height $=$ dorsal-ventral axis), according Galtsoff (1964). After opened, the specimens were analyzed macroscopically for the presence of clinical signs of Perkinsus sp., such as weight loss, pale appearance, shrinkage of mantle and presence of pustules, as previously reported by Bower et al. (1994) and by Bondad-Reantaso et al. (2001).

Cross section of about $5 \mathrm{~mm}$ was made on each specimen, which was fixed in Davidson solution (Shaw and Battle, 1957) for 24-30 hours. The tissues were processed by classical histological technique, including dehydration in a series of increasing alcohol concentrations and embedding in paraffin. Sections of thickness $5 \mu \mathrm{m}$ were cut using a microtome and were stained with Harris haematoxylin and eosin (H\&E) (Howard et al., 2004). The histological sections were analyzed under Olympus light microscope at 40 and $100 \times$. After analysis, the slides were deposited in the Marine Mollusks Laboratory (LMM) at the State University of Santa Cruz, under the care of the first and last authors.

Gills and rectum of each oyster $(n=240)$ were removed and incubated for culturing in Ray's fluid thioglycollate medium - RFTM, developed by Ray (1966), following international protocol (OIE, 2012) with addition of antibiotics (Penicillin and Streptomycin) and antifungal (Nystatin), to inhibit the proliferation of microorganisms. The culture medium was kept in the dark for 7 days at room temperature $\left(20-25^{\circ} \mathrm{C}\right)$. The tissues were macerated and stained in 3\% iodine solution for visualization under a light microscope.

Samples with positive result in RFTM were subjected to PCR. Total DNA extraction was performed from subsamples of the digestive gland and gills, which were preserved in $95 \%$ ethanol. For this step, it was used DNAzol $\left(\right.$ Invitrogen $\left.^{\circledR}\right)$ following the manufacturer's protocol and phenol-chloroform protocol proposed by OIE (2012). For the PCR reactions was used the primer pair PerkITS 85/750, exclusive to members of the genus Perkinsus (except for P. qugwadi) (Casas et al., 2002). The PCR reactions were performed in volumes of $12.5 \mathrm{uL}$, containing 100-200ng of genomic DNA, 1x PCR buffer concentrate, $1.5 \mathrm{mM}$ of $\mathrm{MgCl}_{2}, 2.5 \mathrm{mM}$ of dNTP, 10 picomol of each primer and $1 \mathrm{U}$ Taq DNA polymerase (Invitrogen ${ }^{\circledR}$ ). The DNA of $P$. beihaiensis identified previously by Luz and Boehs (2016) was used as positive control. The protocol included: DNA denaturation at $94{ }^{\circ} \mathrm{C}$ for 5 minutes; 35 cycles of amplification at $94^{\circ} \mathrm{C}$ for 40 seconds, $60^{\circ} \mathrm{C}$ for 40 seconds and $72{ }^{\circ} \mathrm{C}$ for 1 minute followed by a final extension at $72{ }^{\circ} \mathrm{C}$ for 7 minutes. The PCR products were separated on $1.5 \%$ agarose gels, stained with Syber Safe $e^{\circledast}$ and visualized using UV light. Twenty positive samples were randomly selected for DNA sequencing. The samples were sequenced by ACTGene Molecular Analysis (Porto Alegre, Brazil). The obtained sequence was deposited in GenBank.

\subsection{Data processing}

The prevalence of the pathogen was calculated as the number of infected oysters divided by the total number of analyzed oysters (Bush et al., 1997). The infection intensity (analyzed from RFTM), was calculated according to the scale developed by Ray (1954) and modified by Sabry et al. (2009), at the following levels (L): Nil infection: zero hypnospores on the whole slide $(100 \times)(=\mathrm{L} 0)$; Very 


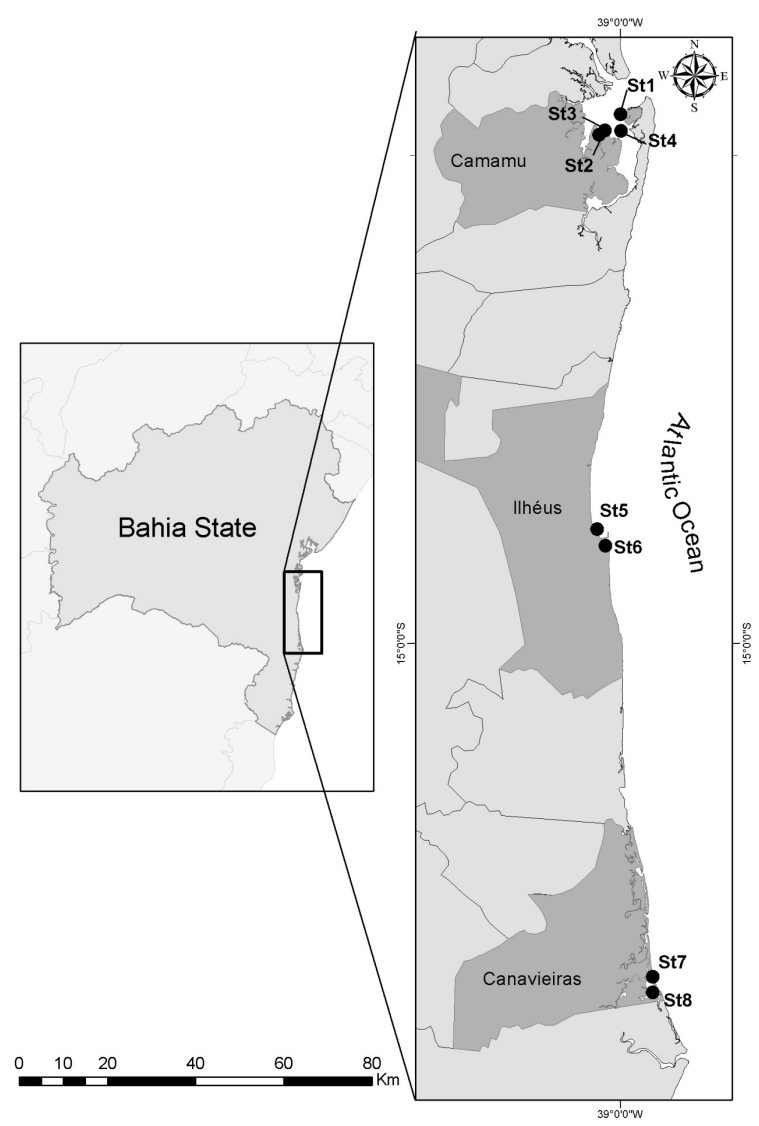

Figure 1. Map of the study area, indicating the collection stations (St1-St8).

Table 1. Information on sampling stations (coordinates, location and specific temperature and salinity data) and results of prevalence (P) of Perkinsus beihaiensis in two species of oysters in Bahia, Brazil, for 240 samples collected between October and December 2014 and analyzed by histology and by Ray's fluid thioglycollate medium (RFTM), as follows: Absence of the species or data; $\mathrm{Cb}=$ Crassostrea brasiliana $; \mathrm{Cr}=$ Crassostrea rhizophorae $\mathrm{S}=$ salinity; $\mathrm{T}=$ temperature.

\begin{tabular}{|c|c|c|c|c|c|c|c|c|}
\hline \multirow{2}{*}{$\begin{array}{l}\text { Sampling } \\
\text { stations }\end{array}$} & \multirow[t]{2}{*}{ Coordinates } & \multirow[t]{2}{*}{ Localities } & \multirow[t]{2}{*}{$\mathbf{T}\left({ }^{\circ} \mathbf{C}\right)$} & \multirow[t]{2}{*}{ S (\%o) } & \multicolumn{2}{|c|}{$\begin{array}{c}\mathrm{P}(\%)- \\
\text { Histology }\end{array}$} & \multicolumn{2}{|c|}{ P(\%) - RFTM } \\
\hline & & & & & $\mathrm{Cr}$ & $\mathrm{Cb}$ & $\mathrm{Cr}$ & $\mathbf{C b}$ \\
\hline St1 & $\begin{array}{c}13^{\circ} 55^{\prime} .818^{\prime \prime} \mathrm{S}, 39^{\circ} . \\
00.9633^{\prime \prime} \mathrm{W}\end{array}$ & Camamu & 29 & 36 & 100 & - & 93.3 & - \\
\hline St2 & $\begin{array}{c}13^{\circ} 56^{\prime} .848^{\prime \prime} \mathrm{S}, 39^{\circ} . \\
00.867^{\prime \prime} \mathrm{W}\end{array}$ & Camamu & 28 & 36 & 96.6 & - & 86.6 & - \\
\hline St3 & $\begin{array}{c}13^{\circ} 57^{\prime} .779 ” \mathrm{~S}, 39^{\circ} .02 ' . \\
948 ” \mathrm{~W}\end{array}$ & Camamu & 27 & 36 & 86.6 & - & 83.3 & - \\
\hline St4 & $\begin{array}{c}13^{\circ} 57^{\prime} .962^{\prime} \mathrm{S}, 39^{\circ} . \\
00.022^{\prime} \mathrm{W}\end{array}$ & Camamu & 27 & 36 & 86.6 & - & 86.6 & - \\
\hline St5 & $\begin{array}{c}14^{\circ} 46 ' .113 " \mathrm{~S}, 39^{\circ} 3 \text { '. } \\
116 ” \mathrm{~W}\end{array}$ & Ilhéus & 26 & 18 & 60.7 & - & 25.0 & - \\
\hline St6 & $\begin{array}{l}14^{\circ} 48^{\prime} 10.21 ' \mathrm{~S} \\
39^{\circ} 2 ' 20.79^{\prime \prime} \mathrm{W}\end{array}$ & Ilhéus & 28 & 30 & 66.6 & 58.3 & 16.6 & 4.16 \\
\hline St7 & $\begin{array}{l}15^{\circ} 41^{\prime} .075^{\prime \prime} \mathrm{S}, \\
38^{\circ} 566^{\prime} 38.066^{\prime} \mathrm{W}\end{array}$ & Canavieiras & 29 & 20 & - & 86.6 & - & 76.6 \\
\hline St8 & $\begin{array}{l}15^{\circ} 42^{\prime} 41.41 ' \mathrm{~S}, \\
38^{\circ} 55^{\prime} 56.177^{\prime \prime} \mathrm{W}\end{array}$ & Canavieiras & 29 & 25 & - & 66.6 & - & 26.6 \\
\hline $\begin{array}{c}\text { Mean } \pm \\
\text { Standard } \\
\text { Deviation }\end{array}$ & - & - & $\begin{array}{c}27.8 \pm \\
1.12\end{array}$ & $\begin{array}{c}29.6 \pm \\
7.67\end{array}$ & $\begin{array}{c}82.8 \pm \\
15.9\end{array}$ & $\begin{array}{c}70.5 \pm \\
14.5\end{array}$ & $\begin{array}{c}65.2 \pm \\
34.6\end{array}$ & $\begin{array}{c}35.7 \pm \\
37.0\end{array}$ \\
\hline
\end{tabular}


mild infection: up to 10 hypnospores on the whole slide $(100 \times)(=\mathrm{L} 1)$; Mild infection: 11-100 hypnospores on the whole slide $(100 \times)(=\mathrm{L} 2)$; Moderate infection: at least 40 hypnospores observed in 10 different fields $(400 \times)$ (= L3); Severe infection: more than 40 hypnospores observed in 10 different fields $(400 \times)(=\mathrm{L} 4)$.

Pearson correlation analysis was used to relate the prevalence data and infection intensity with salinity at the sampling stations and species and a t test was associated to show significant differences. We used the ASSISTAT, version 7.7 beta. A multivariate ordination (Principal Component Analysis - PCA), generated by MVSP software was used to show graphically the correlations. The confidence level was $95 \%$. To ensure high reliability of the salinity values of each place, for these analyzes were used the average of the values obtained in this study with records made over a year in each region, as follows: Lenz and Boehs (2011) and Luz and Boehs (2015) at Camamu, Boehs et al. (2010) at Ilhéus and Zeidan et al. (2012) at Canavieiras.

\section{Results}

The temperature was between 26 and $29{ }^{\circ} \mathrm{C}$ (Mean $27.8{ }^{\circ} \mathrm{C} \pm 1.12$ ) and the salinity between 18 and 36\% (Mean 29.6\%o \pm 7.67) (Table 1).

In molecular analysis to confirm the pathogen, the amplicons showed $700 \mathrm{bp}$, which is the expected size for protozoa of the genus Perkinsus. Sequencing demonstrated that this was $P$. beihaiensis, with 98 to $100 \%$ similarity with the sequences available at NCBI, as deposited by Sanil et al. (2012) and Sabry et al. (2013), to India and the Northeast Brazil, respectively. The obtained sequence was deposited in GenBank with number KX923545.

In an infected oyster collected in station St7, in the municipality of Canavieiras, small pustules measuring approximately $1 \mathrm{~mm}$ in diameter, yellow-white color, were observed in the mantle and gills. In the other specimens $(n=239)$ there was no macroscopic signs of the pathogen.

Trophozoites, typically with a large vacuole and peripheral nucleus, like schizonts (trophozoites dividing) were observed in both species. Trophozoites had sizes between 3 and $10 \mu \mathrm{m}$ (Mean $6.8 \mu \mathrm{m} \pm 2.03$; $\mathrm{n}=240$ ) and were seen mainly in the digestive tract, preferably in the stomach epithelium, but these were observed also in the mantle and adductor muscle, in low-intensity. In the digestive tract, in cases of severe infection, there was moderate hemocytic infiltration and tissue disorganization.

Considering all the sampling stations, the overall mean prevalence in the histology was $82.8 \% \pm 15.9$ in C. rhizophorae and $70.5 \% \pm 14.5$ in C. brasiliana (Table 1).

The results obtained by RFTM showed hypnospores of 2 to $75 \mu \mathrm{m}$, being that the lowest values were observed in cultures from station St3 (2-4 $\mu \mathrm{m})$ and station St7 (2-8 $\mu \mathrm{m})$. The mean prevalence by RFTM was $65.2 \% \pm 34.6$ in C. rhizophorae and $35.7 \% \pm 37.0$ in C. brasiliana (Table 1). The infection was moderate (L3) to severe (L4) in stations St1-St4 and in station St7. In the other stations dominated the null level of infection (L0) or oysters had very mild (L1) or mild infection (L2) (Figure 2 and Figure 3).

Statistical analyzes demonstrated a positive correlation between the prevalence of $P$. beihaiensis and salinity $(\mathrm{r}=0.8798 ; \mathrm{p}<0.01)$. The salinity was also positively correlated with the infection levels: L2 $(r=0.7437$; $p<0.05)$, L3 ( $\mathrm{r}=0.7261 ; \mathrm{p}<0.05)$ and L4 $(\mathrm{r}=0.8841 ; \mathrm{p}<0.01)$ and negatively correlated with the level L0 (absence of infection) $(\mathrm{r}=-0.7526 ; \mathrm{p}<0.05)$. The localities with high prevalence were also strongly correlated with severe levels of infection $(\mathrm{r}=0.8803 ; \mathrm{p}<0.01)$.

At the stations with high salinity (St1-St4 where only occurred C. rhizophorae and St7 where only occurred C. brasiliana), were observed both high prevalence of P. beihaiensis as well high levels of infection. The components 1 and 2 of the Principal Component Analysis - PCA explained $86.5 \%$ of the total variability of the data (Figure 3 ).

\section{Discussion}

In both species of oysters, Perkinsus beihaiensis was detected as the single species of Perkinsus present, with preferential localization in the digestive epithelium, especially in the stomach, and in low numbers, it was also seen in the mantle and adductor muscle. The preferred location of $P$. beihaiensis in the digestive epithelium has been reported in previous studies on the genus Crassostrea (Moss et al., 2008; Sanil et al., 2012; Sabry et al., 2013; Queiroga et al., 2015; Luz and Boehs, 2016).

Oysters with severe infection (level 4, Ray's scale) showed disorganization of gastric and intestinal epithelia and were assessed as impaired by the infection. In turn, both in the mantle and adductor muscle, as in oysters that had a low level of infection, there was no tissue change. Sanil et al. (2012) reported destruction of digestive tubules in some cases of infection by $P$. beihaiensis. Moss et al. (2008) reported epithelial lesions and necrosis in the stomach, intestine and digestive gland. According to Villalba et al. (2004), in more severe Perkinsus infections, such as those caused by $P$. marinus, maceration of the adductor muscle may occur, with consequent involuntary opening of valves, weight loss, shrinkage of the mantle, impairment of the immune system and death of the host.

Comparing the results of prevalence of $P$. beihaiensis of this study with others obtained for Crassostrea spp. in Brazil, it was found that the values obtained on the coast of Bahia are higher. Considering only the results obtained by histology, Sabry et al. (2013) found prevalences between 3 and $20 \%$ in the State of Ceará, in a region with a mean salinity of 33.1\%o and Queiroga et al. (2015) found mean prevalence of $48.9 \%$ in the State of Paraíba, but did not mention salinity. In the State of Bahia, Luz and Boehs (2016) previously found an overall mean of $93.3 \%$ in the Camamu Bay, in a region with a mean salinity of $28.4 \%$. In this study, the salinity values were generally above $20 \%$, and the overall mean prevalence of $P$. beihaiensis was $78.7 \%$, considering the two species of oysters. 


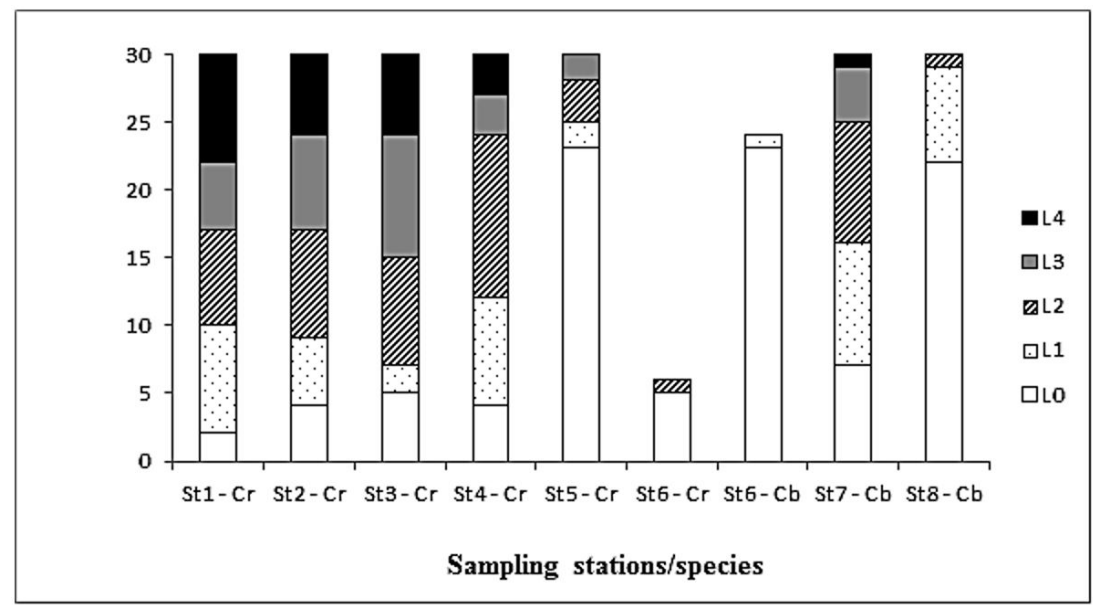

Figure 2. Absolute frequency of infection levels of Perkinsus beihaiensis of Crassostrea rhizophorae (Cr) and C. brasiliana $(\mathrm{Cb})$ from coast of Bahia, observed under light microscopy after cultivation in Ray's fluid thioglycollate medium - RFTM. $\mathrm{n}=240$. Infection levels according to the classification of Ray (1954), where: L0 = Nil infection; L1 = Very mild infection; L2 = Mild infection; L3 = Moderate infection; L4 = Severe infection.

\section{PCA case Scores}

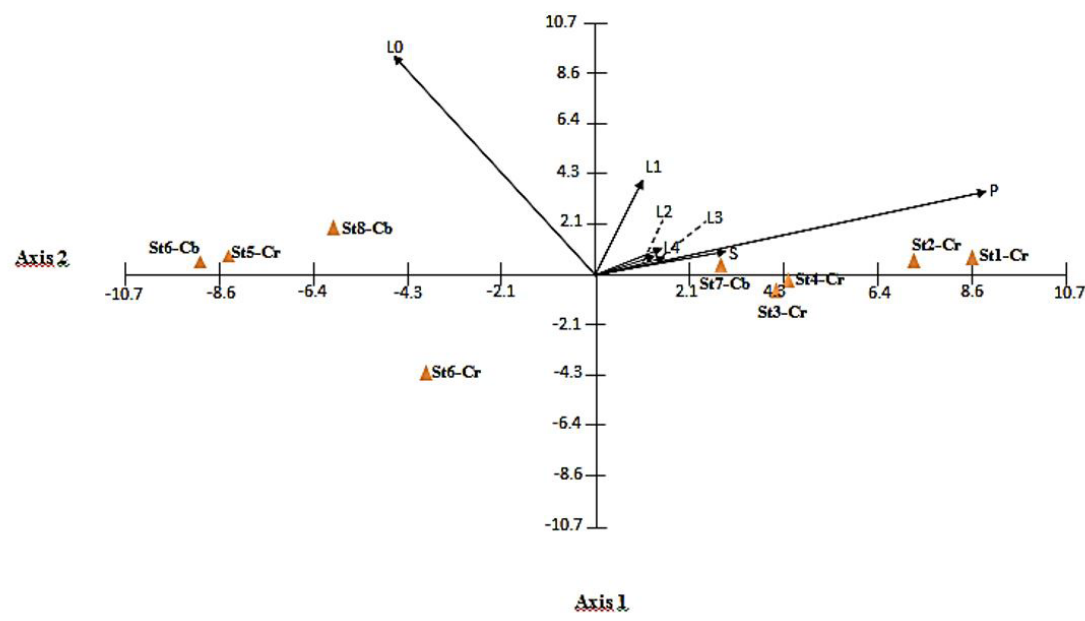

Figure 3. Graphic result of Principal Component Analysis (PCA), showing a positive correlation between the prevalence (P) and intensity of infection (levels L0-L4) of Perkinsus beihaiensis with salinity (S) in the oysters: Crassostrea rhizophorae $(\mathrm{Cr})$ and $C$. brasiliana $(\mathrm{Cb}) . \mathrm{St}=$ sampling stations $(\mathrm{St} 1-\mathrm{St} 8)$.

Our results showed positive correlations between salinity and both prevalence and infection intensity, which reinforces results from previous studies (Volety, 2008; La Peyre et al., 2010). According Villalba et al. (2004), in some places, the seasonal variations of salinity and of temperature modulate the occurrence of species of the genus Perkinsus. In Brazil, this pathogen has been detected so far only in the Northeast region of the country where, coincidentally, temperatures are high throughout the year.

With reference to the prevalence and levels of infection generally higher in $C$. rhizophorae in relation to $C$. brasiliana, we conclude that this result was in principle affected by salinity levels, since the first species was collected in more saline places. However, a higher prevalence among $C$. rhizophorae was also seen in station St6 where there was the simultaneous occurrence of the two species, suggesting that perhaps $C$. rhizophorae is more severely affected by $P$. beihaiensis than C. brasiliana. Thus, ecological differences between the two oyster species (C. rhizophorae inhabits intertidal levels slightly higher than $C$. brasiliana) may have influence on susceptibility to $P$. beihaiensis.

As for the higher sensitivity of the detection of P. beihaiensis in histology relative to RFTM, we conclude 
that this difference is due to the use of different organs in each of the techniques. The protocol currently used (OIE, 2012) indicates the use of the rectum and the gills for RFTM, where seems to be a lower concentration of the pathogen in relation to the stomach, organ usually included in the histological analysis. This difference was already observed in previous studies (Sabry et al., 2009, 2013; Ferreira et al., 2015; Luz and Boehs, 2016). We suggest the use of same organs in histology and RFTM (and also in PCR), to obtain greater uniformity in the diagnosis.

The presence of pustules on an infected oyster in station St7 indicates the possibility of using presumptive diagnosis as a diagnostic complement, however, as we observed the event in a single oyster, the reliability of occurring macroscopic evidence of the pathogen in question is still low.

It is concluded that $P$. beihaiensis does not affect massively the health of the oysters in the region at this moment. However, in order to the development of oyster farming, periodic monitoring of this pathogen should be emphasized.

\section{Acknowledgements}

The authors would like to thank the FAPESB (Fundação de Amparo à Pesquisa do Estado da Bahia) for granting the scholarship to first author, and for financing the project, TSC 0010/2011. To Marina Boehs for the final revision of the English.

\section{References}

BOEHS, G., MAGALHÃES, A.R.M., SABRY, R.C. and CEUTA, L.O., 2012. Parasitos e patologias de bivalves marinhos de importância econômica da costa brasileira. In: A.T. SILVA-SOUZA, M.L.A. LIZAMA and R. TAKEMOTO, eds. Patologia e sanidade de organismos aquáticos. Maringá: Massoni, Associação Brasileira de Patologistas de Organismos Aquáticos, pp. 165-193.

BOEHS, G., VILLALBA, A., CEUTA, L.O. and LUZ, J.R., 2010. Parasites of three commercially exploited bivalve mollusc species of the estuarine region of the Cachoeira river, Ilhéus, Bahia, Brazil. Journal of Invertebrate Pathology, vol. 103, no. 1, pp. 43-47. PMid:19850046. http://dx.doi.org/10.1016/j.jip.2009.10.008.

BONDAD-REANTASO, M.G., MCGLADDERY, S.E., EAST, I. and SUBASINGHE, R.P., 2001. Asia diagnostic guide to aquatic animal diseases. Rome: FAO. 240 p. FAO Fisheries Technical Paper, no. 402/2.

BOWER, S.M., MCGLADDERY, S.E. and PRICE, I.M., 1994. Synopsis of infectious diseases and parasites of commercially exploited shellfish. Annual Review of Fish Diseases, vol. 4, no. 1, pp. 1-199. http://dx.doi.org/10.1016/0959-8030(94)90028-0.

BUSH, A.O., LAFFERTY, K.D., LOTZ, J.M. and SHOSTAK, A.W., 1997. Parasitology meets ecology on its own terms: Margolis et al. revisited. The Journal of Parasitology, vol. 83, no. 4, pp. 575-583. PMid:9267395. http://dx.doi.org/10.2307/3284227.

CASAS, S.M., VILLALBA, A. and REECE, K.S., 2002. Study of perkinsosis in the carpet shell clam Tapes decussatus in Galicia (NW Spain). I. Identification of the aetiological agent and in vitro modulation of zoosporulation by temperature and salinity. Diseases of Aquatic Organisms, vol. 50, no. 1, pp. 51-65. PMid:12152905. http://dx.doi.org/10.3354/dao050051.

DANTAS NETO, M.P., 2015. Patógenos na ostra Crassostrea rhizophorae de estuários da costa setentrional do Nordeste brasileiro. Ceará: Universidade Federal do Ceará. 119 p. Doctoral Thesis.

FERREIRA, L.P., SABRY, R.C., SILVA, P.M., GESTEIRA, T.C.V., ROMÃO, L.S., PAZ, M.P., FEIJÓ, R.G., DANTAS NETO, M.P. and MAGGIONI, R., 2015. First report of Perkinsus beihaiensis in wild clams Anomalocardia brasiliana (Bivalvia: Veneridae) in Brazil. Experimental Parasitology, vol. 150, pp. 67-70. PMid:25088443. http://dx.doi.org/10.1016/j.exppara.2014.07.012.

GALTSOFF, P.S., 1964 [viewed 5 May 2016]. The American oyster Crassostrea virginica (Gmelin) [online]. Washington: US Government Printing Office. 480 p. Fish and Wildlife Service Bulletin, vol. 64, no. 1. Available from: onlinelibrary.wiley.com/ doi/10.4319/1o.1966.

HOWARD, D.W., LEWIS, E.J., KELLER, B.J. and SMITH, C.S., 2004. Histological Techniques for Marine Bivalve Mollusks and Crustaceans. Oxford: NOAA Technical Memorandum. 218 p.

LA PEYRE, M.K., CASAS, S.M., GAYLE, W. and LA PEYRE, J., 2010. The combined influence of sub-optimal temperature and salinity on the in vitro viability of Perkinsus marinus, a protistan parasite of the eastern oyster Crassostrea virginica. Journal of Invertebrate Pathology, vol. 105, no. 2, pp. 176-181. PMid:20600094. http://dx.doi.org/10.1016/j.jip.2010.06.010.

LENZ, T. and BOEHS, G., 2011. Ciclo reproductivo del ostión de manglar Crassostrea rhizophorae (Bivalvia: Ostreidae) en la Bahía de Camamu, Bahia, Brasil. Revista de Biología Tropical, vol. 59, no. 1, pp. 137-149. PMid:21516642.

LUZ, M.D.S.A. and BOEHS, G., 2016. Perkinsus beihaiensis infectando a ostra Crassostrea rhizophorae em cultivo e em estoque natural na Baía de Camamu, Bahia, Brasil. Brazilian Journal of Veterinary Research and Animal Science, vol. 53, no. 2, pp. 191.

LUZ, M.S.A. and BOEHS, G., 2015. Parasites in the oyster Crassostrea rhizophorae from farmed and natural stocks in the Bay of Camamu, Bahia, northeastern Brazil. Journal of Parasitology and Vector Biology, vol. 7, no. 6, pp. 120-128. http://dx.doi. org/10.5897/JPVB2015.0198.

MOSS, J.A., XIAO, J., DUNGAN, C.F. and REECE, K.S., 2008. Description of Perkinsus beihaiensis n. sp., a new Perkinsus sp. parasite in oysters of Southern China. The Journal of Eukaryotic Microbiology, vol. 55, no. 2, pp. 117-130. PMid:18318865. http:// dx.doi.org/10.1111/j.1550-7408.2008.00314.x.

OFFICE INTERNATIONAL DES EPIZOOTIES - OIE, 2012. Manual of diagnostic test for aquatic animals. Paris: World Health Organization.

QUEIROGA, F.R., VIANNA, R.T., VIEIRA, C.B., FARIAS, N.D. and DA SILVA, P.M., 2015. Parasites infecting the cultured oyster Crassostrea gasar (Adanson, 1757) in Northeast Brazil. Parasitology, vol. 142, no. 6, pp. 756-766. PMid:25553815. http://dx.doi.org/10.1017/S0031182014001863.

RAY, S.M., 1954. Biological studies of Dermocystidium marinum, a fungus parasite of oysters. Houston: Rice Institute. 120 p. Doctoral Thesis in Natural Sciences.

RAY, S.M., 1966. A review of the culture method for detecting Dermocystidium marinum, with suggested modifications and precautions. Proceedings of the National Shellfisheries Association, vol. 54, no. 1, pp. 55-69. http://dx.doi.org/10.2983/0730-8000(2006)25. 
SABRY, R.C., GESTEIRA, T.C.V., MAGALHÃES, A.R.M., BARRACCO, M.A., GUERTLER, C., FERREIRA, L.P., VIANNA, R.T. and SILVA, P.M., 2013. Parasitological survey of mangrove oyster, Crassostrea rhizophorae, in the Pacoti river estuary, Ceará state, Brazil. Journal of Invertebrate Pathology, vol. 112, no. 1, pp. 24-32. PMid:23147104. http://dx.doi.org/10.1016/j. jip.2012.10.004.

SABRY, R.C., ROSA, R.D., MAGALHÃES, A.R., BARRACCO, M.A., GESTEIRA, T.C. and SILVA, P.M., 2009. First report of Perkinsus sp. infecting mangrove oysters Crassostrea rhizophorae from the Brazilian coast. Diseases of aquatic organisms, vol. 88, no. 1, pp. 13-23.

SANIL, N.K., SUJA, G., LIJO, J. and VIJAYAN, K.K., 2012. First report of Perkinsus beihaiensis in Crassostrea madrasensis from the Indian subcontinent. Diseases of Aquatic Organisms, vol. 98, no. 3, pp. 209-220. PMid:22535871. http://dx.doi. org/10.3354/dao02440.
SHAW, B.L. and BATTLE, H.I., 1957. The gross and microscopic anatomy of the digestive tract of the oyster Crassostrea virginica (Gmelin). Canadian Journal of Zoology, vol. 35, no. 1, pp. 325347. http://dx.doi.org/10.1139/z57-026.

VILLALBA, A., REECE, K.S., ORDÁS, M.C., CASAS, S.M. and FIGUERAS, A., 2004. Perkinsosis in molluscs: a review. Aquatic Living Resources, vol. 17, no. 4, pp. 411-432. http:// dx.doi.org/10.1051/alr:2004050.

VOLETY, A.K., 2008. Effects of salinity, heavy metals and pesticides on health and physiology of oysters in the Caloosahatchee Estuary, Florida. Ecotoxicology, vol. 17, no. 7, pp. 579-590. PMid:18686029. http://dx.doi.org/10.1007/s10646-008-0242-9.

ZEIDAN, G.C., LUZ, M.S.A. and BOEHS, G., 2012. Parasites of economically important bivalves from the southern coast of Bahia State, Brazil. Revista Brasileira de Parasitologia Veterinária, vol. 21, no. 4, pp. 391-398. PMid:23295820. http://dx.doi.org/10.1590/ S1984-29612012000400009. 